\author{
22-24 November, $2019 \quad$ Paris, France
}

\title{
Quantitative Analysis Of Trace Metal In Water And Soft Tissues Of Balanus Amphitrite In Nandikadal Lagoon, Sri Lanka
}

\author{
Sivashanthini Kuganathan ${ }^{1}$, Dhanushka Dilini Jayaweera ${ }^{2}$ Shivatharshini Yohi ${ }^{3}$, Kuttithamby \\ Gunaalan $^{4}$ \\ Department of Fisheries, Faculty of Science, University of Jaffna, Sri Lanka
}

\begin{abstract}
Due to long-term military activities carried out in Nandikadal lagoon situated at Mullaitivu, Sri Lanka, there are high possibilities to impact water and biota with heavy metals .Balanus amphitrite) Barnacles (has been found as a strong candidate for biomonitoring of trace metals . Therefore, the present study describes the impacts of trace metal pollution on water and the soft tissues of Balanus amphitrite. Water samples and barnacles were collected from two locations of the lagoon for four months during the dry and wet seasons .Quantitative analysis of trace metals ) $\mathrm{Cd}, \mathrm{Cu}, \mathrm{Cr}, \mathrm{Pb}$ and $\mathrm{Zn}$ ( were detected in the water and tissue samples using flame atomic absorption spectrometry $. \mathrm{Cd}, \mathrm{Cr}, \mathrm{Pb}$ and $\mathrm{Cu}$ found in tissues of barnacles were several times higher than the International recommended level except for $\mathrm{Zn}$. The concentration of $\mathrm{Pb}$ in tissues of barnacles showed a significant $(\mathrm{p}<0.05)$ spatial variation .The $\mathrm{Cd}$ and $\mathrm{Cu}$ concentrations obtained in soft tissues showed significant $) p<0.05$ ) seasonal variations .The concentration of $\mathrm{Cr}$ in water showed a significant $) \mathrm{p}<0.05$ ) spatial variation and other trace metals ) $\mathrm{Pb}, \mathrm{Cd}$ (except $\mathrm{Zn}$, showed significant $) \mathrm{p}<0.05$ ) seasonal variations .There were significant positive correlations between water and soft tissues with respect to $\mathrm{Cd}) p=0.000 \&$ $r=0.893$ (and $\mathrm{Pb}$ ) $p=0.002 \& r=0.435$. ( $\mathrm{Zn}$ found in samples showed negative correlation between water and soft tissues. According to this results Balanus amphitrite has an ability to accumulate trace metals several times greater than in the lagoon water .Therefore, Balanus amphitrite is a strong net-accumulator of $\mathrm{Cd}, \mathrm{Pb}, \mathrm{Zn}, \mathrm{Cu}, \mathrm{Cr}$. Hence, it is a good choice to be used as a bioindicator organism to find the level impact of trace metal contamination .
\end{abstract}

Key words :Accumulate, Biomonitoring, Bio indicator, Net-accumulator, Trace metals 


\title{
$2^{\text {nd }}$ International Conference on Research in SCIENCE ENGINEERING AND TECHNOLOGY
}

\author{
22-24 November, $2019 \quad$ Paris, France
}

\section{Introduction}

Nandikadal lagoon is the place where a decisive battle against terrorism took place in last decade (Rodrigo, 2017) .Specific nature of long-term military activities carried out in Nandikadal lagoon area with military equipment such as weapons, ammunition and different busters have caused the anomalies of pollution with heavy metals .Balanusa mphitrite is a suspension feederthat takes up metal both directly from lagoon water and from the suspended particles during feeding. Balanus amphitrite sare also accumulated extremely high concentrations of tracemetals, exceeding those in most other invertebrate (Rainow and Wang, 2001).

They have comparatively very high uptake rates of trace metals from water, food or any other solutions) Rainbow \& White, 1989 .(They feed by filtering suspended matter as well as tropic transfer appears to be the predominant source of the large quantity of heavy metals taken up and subsequently accumulated .Also, they indicate possibleusefulness indicator of Zinc pollution) Walker et al., 1975.(

The main purpose of the present study was to quajntify the impacts of trace metal pollution on water and the soft tissues of Balanus amphitrite .

\section{Methods}

Samples w erecollected from two sampling sites )A and B (in the Lagoon where good distribution of barnacles are found .The site A was the lagoon area which is oriented to the lagoon side and the site B was the estuary which is located near to the mouth of the estuary. and water samples were collected from each location Balanus amphitrite The for four months during the dry and wet seasons. Barnacles were placed in clean polythene bags and transported $\mathrm{C}$ using ice gel packets in stiriform boxes $4^{0}$ - at. WC using ice gel $4^{0}$ - ater sample were kept at .packets during transport

\subsection{Trace metal analysis in Barnacles and water sample:}

$\mathrm{S}$ oft tissuesof barnacles were removed. $-\mathrm{C}^{0}$ Each sample were dried to constant weight at 60 days $\mathrm{C}$ using hot air sterilizer for few $65^{\circ}$. Then dried sample were powdered using grinder. The of acid digestion was applied for sample digestion (B3050) USEPA method. The analysis of trace metals of $\mathrm{Zn}, \mathrm{Cu}, \mathrm{Pb}, \mathrm{Cr}, \mathrm{Cd}, \mathrm{Fe}$ were conducted using Atomic Absorption in National Building Research Organization in Colombo (ATS 230 ) (AAS) Spectrophotometer (NBRO) 


\title{
$2^{\text {nd }}$ International Conference on Research in SCIENCE ENGINEERING AND TECHNOLOGY
}

\author{
22-24 November, $2019 \quad$ Paris, France
}

\subsection{Data analysis}

Data w eresubjected to statistical tests of significance using the Student t-test and Analysis of Variance )one-way ANOVA (at $p<0.05$ to access whether heavy metal concentrations vary significantly between sites and seasons .

\section{Results and Discusion}

The concentration of $\mathrm{Pb}$ in tissues of barnacles showed a significant $(\mathrm{p}<0.05)$ spatial variation . The $\mathrm{Cd}$ and $\mathrm{Cu}$ concentrations obtained in soft tissues showed significant $) \mathrm{p}<0.05$ ) seasonal variations .

The concentration of $\mathrm{Cr}$ in water showed a significant $) \mathrm{p}<0.05)$ spatial variation and other trace metals ) Pb,Cd (except $\mathrm{Zn}$, showed significant $) \mathrm{p}<0.05$ ) seasonal variations . The maximum concentration of $\mathrm{Cd}, \mathrm{Pb}, \mathrm{Cu}$ and $\mathrm{Cr}$ in water were recorded during the dry season .But for the $\mathrm{Zn}$, the maximum concentration was recorded during the wet season.

There was a strong significant $p=0.000, r=0.893$ (positive correlation between $\mathrm{Cd}$ concentration in water and soft tissues of Balanus amphitrite. There was significant $) p=0.002$, $r=0.435$ (positive correlation between $\mathrm{Pb}$ concentration in water and soft tissues of Balanus amphitrite. There was a significant ) $p=0.016, r-=0.036$ (negative correlation between $\mathrm{Zn}$ concentration in water and soft tissues of Balanus amphitrite. The $\mathrm{Zn}$ concentration during the dry season was distinctly high in water but $\mathrm{Zn}$ concentration in soft tissues was low in the same season. There was no significant) $p=0.058, r-=0.275$ (correlation between $\mathrm{Cu}$ concentration in water and soft tissues of Balanus amphitrite. Similarly,there was no significant $) p=0.496, r$ - $=0.101$ (correlation between $\mathrm{Cr}$ concentration in water and soft tissues of Balanus amphitrite.

\section{Conclusions:}

In the present study, the maximum level of $\mathrm{Cd}, \mathrm{Pb}, \mathrm{Cu}$ and $\mathrm{Cr}$ found in soft tissues of Balanus amphitrite exceeded the international recommended level in dry tissues except for $\mathrm{Zn}$. ,ThereforeBalanus amphitrite is a strong net-accumulator of $\mathrm{Cd}, \mathrm{Pb}, \mathrm{Zn}, \mathrm{Cu}, \mathrm{Cr}$.Hence, it is a good choice to be used as a bioindicator organism to find the level impact of trace metal contamination. 


\title{
$2^{\text {nd }}$ International Conference on Research in SCIENCE ENGINEERING AND TECHNOLOGY
}

\author{
Paris, France
}

\section{References}

Rainbow, P. S. and Wang, W. X., 2001. Comparative assimilation of $C d, C r$, Se and Zn by the barnacle Elminus modestus from phytoplankton and zooplankton diets., Hong Kong: s.n.

Rainbow, P .\& White, S., 1989 .Comparative accumulation of cobalt by three crustaceans : decapod, an amphipod and a barnacle, London :s.n.

Rodrigo,M.,2017.www.Sundaytimes.lk].Online[Availableat:http//:www.sundatimes.lk/17611/ news/nandikadal-lagoon-fish-perished-without-oxygen-says-nara-244783html ]Accessed 12072018[ 